\title{
REGIONALNO PLANIRANJE IN REGIONALNI RAZVOJ MED TEORIJO IN PRAKSO
}

Oddelek za geografijo Filozofske fakultete Univerze v Ljubljani je 27. septembra 2005 organiziral strokovno-znanstveno srečanje ob 75-letnici akademika prof. dr. Igorja Vrišerja z naslovom Regionalno planiranje in regionalni razvoj v teoriji in praksi. Akademik prof. dr. Igor Vrišer je na Oddelku za geografijo Filozofske fakultete Univerze v Ljubljani s svojim dolgoletnim znanstvenim, strokovnim, raziskovalnim in pedagoškim delom na geografskem metodološkem področju, na področju regionalnega planiranja in urbane geografije ter na področju ekonomske geografije pomembno prispeval k razvoju geografske znanosti, njeni mednarodni odmevnosti in ugledu Slovenije. Prof. dr. Igor Vrišer je neposredno in posredno $\mathrm{v}$ sodelovanju z drugimi planerskimi disciplinami oblikoval temelje slovenske regionalnoplanerske stroke.

Strokovnega srečanja, ki je potekalo na Oddelku za geografijo Filozofske fakultete se je udeležilo 62 udeležencev, ki so prihajali iz različnih izobraževalnih (Filozofska fakulteta, Fakulteta za gradbeništvo in geodezijo, Biotehniška fakulteta, Šolski center Ptuj), raziskovalnih (Geografski inštitut ZRC SAZU, Urad za makroekonomske analize in razvoj), vladnih (Ministrstvo za okolje in prostor, Ministrstvo za notranje zadeve, Služba Vlade RS za lokalno samoupravo in regionalni razvoj, Statistični urad RS) in planerskih institucij (Regionalna razvojna agencija Ljubljanske urbane regije, Acer - Novo mesto).

Udeležence strokovnega srečanja sta pozdravila predstojnik Oddelka za geografijo Filozofske fakultete dr. Krevs in prodekan Filozofske fakultete dr. Urbanija. Predsednik državnega zbora, g. Cukjati, in minister za okolje in prostor, g. Podobnik, sta opravičila svojo odsotnost. V nadaljevanju srečanja je 16 geografov in predstavnikov drugih strok, ki so aktivne na področju regionalnega in prostorskega planiranja, predstavilo referate o različnih vidikih regionalnega planiranja in regionalnega razvoja, ki so bili usmerjeni tako v teoretskometodološka in vsebinska vprašanja razumevanja preteklih in sodobnih regionalnih razvojnih teženj kot tudi v proučevanje temeljnih strokovnih spoznanj o sedanjih regionalnih razmerah in njihovemu vrednotenju.

V sklepni razpravi so se izoblikovali naslednji sklepi:

1. na institucionalni in praktični ravni je potrebno jasno določiti vlogo regionalnega planiranja v sistemu planiranja v Sloveniji;

2. o vsebinah povezanih $\mathrm{z}$ regionalnim planiranjem in regionalnim razvojem je potrebno več govoriti in razpravljati, zato bi bilo dobro, da bi bila podobna srečanja, kot je bil posvet Regionalno planiranje in regionalni razvoj, $v$ teoriji in praksi bolj pogosta;

3. $\mathrm{v}$ razprave s področja regionalnega razvoja in planiranja je potrebno bolj aktivno vključevati predstavnike regionalnih razvojnih agencij;

4. strokovno srečanje, ki je bilo posvečeno življenjskemu jubileju akademika prof. dr. Igorja Vrišerja, je doseglo svoj namen; s svojo interdisciplinarnostjo je pomenilo pomemben prispevek k razpravi o pomembnih teoretičnih in praktičnih vidikih spodbujanja skladnejšega regionalega razvoja; 
5. publikacijo Dela Oddelka za geografijo, v katerem so objavljeni članki - referati (Dela 24), je potrebno posredovati najširšemu krogu zainteresirane strokovne javnosti.

Strokovno-znanstveno srečanje Regionalno planiranje in regionalni razvoj v teoriji in praksi je bil pomemben dogodek, ki je ponovno združil strokovnjake iz različnih področij. Glavni uspeh srečanja je bila ravno dosežena interdisciplinarnost in pregled najnovejših dosežkov ter izzivov s področja spodbujanja skladnejšega regionalnega razvoja v Sloveniji $\mathrm{v}$ duhu novih izzivov, ki jih pred teoretike in praktike postavljajo nov sistem spodbujanja skladnega regionalnega razvoja $\mathrm{v}$ Sloveniji, izzivi skupne evropske regionalne politike in globalizacija.

Simon Kušar 